Journal Universitas Muhammadiyah Gresik Engineering, Social Science, and Health International Conference (UMGESHIC)

UMGCINMATIC : $1^{\text {st }}$ Rethinking Education during Covid-19 Era: Challange and Innovation

\title{
MARKETING STRATEGY AMID THE COVID-19 PANDEMIC USING SWOT ANALYSIS AT KIMOCHI EATERY GRESIK RESTORAN
}

\author{
Author \\ Arif Rubihanto ${ }^{1}$, Elly Ismiyah ${ }^{2}$ \\ Industrial Engineering Study Program, University of Muhammadiyah Gresik \\ E-mail: arif_rubihanto@yahoo.com, Ismi_elly@umg.ac.id
}

\begin{abstract}
Kimochi Eatery Gresik restaurant is an industry engaged in the culinary field that sells a variety of Japanese-style food and drinks located on Jl. Kalimantan No. 159 GKB, Gresik. This restaurant has been established since the beginning of 2015 and sells its flagship menu, namely taichan satay. The strategy implemented by Kimochi Eatery Restaurant for marketing its products is good, but since the emergence of the COVID-19 pandemic in early 2020, precisely in February, Kimochi Eatery Restaurant has experienced a decline in product sales, this can be caused by government policies that implement PPKM in the JavaBali area, which limits people's mobility and requires restrictions on operating hours, therefore companies are required to plan better marketing strategies. This research was conducted to formulate a marketing strategy according to the company's internal and external conditions. Analysis of the internal environment and the external environment can be used as the main reference for improving marketing strategies. The approach used in this research is SWOT analysis. In the SWOT analysis, there are several matrices, namely IFE and EFE matrices, which are used to find the weighted score, IE Matrix, which is used to find the cell division of the company, and the SWOT matrix to formulate alternative strategies. From the resulting research, the IFE matrix scores 2,972 while the EFE matrix scores 2,986. From the weight of the score that has been obtained, the company can implement a strategy of hold and maintain.
\end{abstract}

Keywords: Marketing strategy, SWOT, IFE-EFE Matrix

\section{INTRODUCTION}

Currently, the development of the global economy has experienced a very drastic decline due to the Corona Virus Disease 2019 (COVID-19) which has become a worldwide pandemic. The World Health Organization (WHO) has officially declared that the COVID-19 outbreak is a global pandemic that has an impact on the establishment of an international health emergency status. The COVID-19 pandemic set by the WHO has forced all countries to quarantine areas, especially in Indonesia.

In response to the determination of COVID-19 as a pandemic, the Indonesian government implemented recommendations such as maintaining physical distance (physical distancing) and enacting Government Regulation (PP) Number 21 of 2020 concerning Large-Scale Social Restrictions. MSME sector. As has happened in several parts of Indonesia, MSMEs in the city of Gresik also feel the impact of the enactment of government regulations, one of which is the Kimochi Eatery Restaurant. 
UMGCINMATIC : $\mathbf{1}^{\text {st }}$ Rethinking Education during Covid-19 Era: Challange and Innovation Volume 1 No 2

SWOT stands for the internal environment strengths and weaknesses, as well as the external environment opportunities and threats faced by the business world (Rangkuti 2015: 20). Strengths include internal capabilities, resources, and positive situational factors that can help companies serve customers to achieve their goals, weaknesses include internal limitations and negative situational factors that can hinder the performance of a business, opportunities include factors that advantageous in the external environment that the company can use to gain profits, and threats include factors in the unfavorable external environment that present challenges to the company's performance (Kotler and Armstrong 2008: 64).

Kimochi Eatery restaurant itself definitely has strengths, weaknesses, opportunities, and threats during the COVID-19 pandemic. From these strengths, weaknesses, opportunities, and threats, you can create a marketing strategy at Kimochi Eatery Restaurant by using strengths to take advantage of opportunities, using strengths to overcome threats, minimizing weaknesses by taking advantage of opportunities, and minimizing weaknesses and avoiding threats.

\section{METHODS}

\section{Preliminary studies}

The preliminary study is the initial stage in the methodology of this research. At this stage the researcher conducts a preliminary study by going directly to the company. Here the researcher will find the problems that will be faced by the company, from the various problems found by the researcher then choose one problem to be a problem in this research, and then look for solutions to solve it.

Field Study

Field observation studies are company research used to find out the situation and conditions that exist in the company so that problems can be found.

\section{Study of literature}

Literature study is an activity to collect information from several references that are relevant to the problems to be discussed. The aim is to broaden and deepen the insight and knowledge of researchers regarding theories related to the problems studied. The theory is used as the basis for processing data, analyzing the results of data processing.

\section{Formulation of the problem}

The formulation of the problem is intended so that what will be carried out is in accordance with the objectives to be achieved and does not deviate. In addition, the formulation of the problem also serves to clarify the scope of the problem. In this research, the problem that becomes the object of research is what are the proposed marketing strategies in an effort to carry out marketing strategies at Kimochi Eatery Gresik Restaurant using SWOT analysis.

\section{Research purposes}

The purpose of this study is to determine the current condition of the company based on the company's strengths, weaknesses, opportunities and threats as well as to propose the most appropriate marketing strategy during the COVID-19 pandemic.

\section{Data collection}

At this stage, the data that will be needed for a reference for this research is collected. The research collects the company's environmental analysis data by:

\section{A. Company environmental analysis}

- Distribution of open questionnaire 
- Determination of internal and external factors using literature from journals that are in accordance with the situation at Kimochi Eateru Restaurant Gresik.

\section{B. Determination of Respondents}

In this study, respondents were taken from the owner of the Kimochi Eatery Restaurant, the deputy head of the restaurant, and 3 restaurant employees who have worked for a long time and understand Gresik's Kimochi Eatery Restaurant, so a total of 5 respondents, this determination was based on people who know about Kimochi Eatery Gresik Restaurant either from the process or product quality.

\section{Distribution of questionnaires}

To respondents the questionnaire was distributed to respondents who had been determined, namely 5 people, from 5 people were given several sheets of paper containing questions that the respondents had to fill out properly and in accordance with the directions or instructions that were already on the questionnaire sheet and assistance to the questionnaire giver. so that if there are still those who don't understand, they can ask questions and give correct directions.

\section{Data processing}

The data that can be obtained will be used in data processing which includes the following activities:

\section{IFE and EFE Matrix Design}

Provide an open questionnaire to determine internal and external factors.

\section{Weight Determination}

Each internal and external factor then the rating process is useful for the process of making an internal matrix and an external matrix. The internal factor matrix is used to determine the company's internal factors related to strengths and weaknesses that are considered important (Sugianto et al, 2017). The internal factor matrix serves to summarize and evaluate the main strengths and weaknesses in the functional areas of the business, and also provides a basis for identifying and evaluating relationships among areas. An IFE Matrix can be developed in five steps (David, 2011).

\section{Scoring}

Calculates the number of weighted scores. This value is to determine the position of the organization on the SWOT analysis diagram. You do this by sorting the internal and external factors below, starting from the least influential to the very influential (less influential =1).

\section{SWOT Matrix Design}

The SWOT matrix is the creation of a matrix based on internal and external factors owned by Kimochi Eatery Restaurant which is needed for the formulation of alternative strategies.

\section{Analysis and Discussion}

At this stage the data obtained from the respondents will be identified and grouped into internal and external strategic factors.

\section{RESULT AND DISCUSSION}

At this stage, conclusions will be drawn from the results of the analysis and research carried out and suggestions will be given constructive criticism. 
Table 1. Strengths and weaknesses of "Kimochi Eatery Gresik" Restaurant

\begin{tabular}{|c|c|}
\hline Strength & Weakness \\
\hline $\begin{array}{ll}\text { - } & \text { Affordable } \\
& \text { product prices }\end{array}$ & $\begin{array}{l}\text { Insufficient parking } \\
\text { space }\end{array}$ \\
\hline $\begin{array}{l}\text { - Good product } \\
\text { taste }\end{array}$ & $\begin{array}{l}\text { Promotion is not } \\
\text { maximized }\end{array}$ \\
\hline $\begin{array}{l}\text { - } \quad \text { Various } \\
\text { products }\end{array}$ & $\begin{array}{l}\text { Employees are not } \\
\text { disciplined in } \\
\text { implementing } \\
\text { health protocols }\end{array}$ \\
\hline 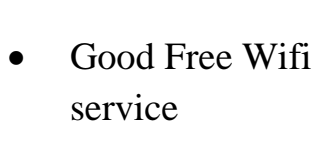 & $\begin{array}{l}\text { - Health facilities } \\
\text { (Handsanitizer) in a } \\
\text { sufficient location }\end{array}$ \\
\hline $\begin{array}{l}\text { - Strategic } \\
\text { location }\end{array}$ & $\begin{array}{l}\text { Poor room } \\
\text { conditions }\end{array}$ \\
\hline
\end{tabular}

Table 2. Opportunities and threats for "Kimochi Eatery Gresik" Restaurant

\begin{tabular}{|l|l|}
\hline \multicolumn{1}{|c|}{ Opportunity } & \multicolumn{1}{|c|}{ Threat } \\
\hline Easier access & $\bullet \begin{array}{l}\text { There are } \\
\text { superior } \\
\text { competitors } \\
\text { Environmental } \\
\text { conditions often } \\
\text { flood during the } \\
\text { rainy season } \\
\text { The development } \\
\text { of technological } \\
\text { progress }\end{array}$ \\
$\begin{array}{l}\text { Do a lot of orders } \\
\text { from customers } \\
\text { The existence of } \\
\text { competitors } \\
\text { the implementation } \\
\text { of the New Normal } \\
\text { by the district } \\
\text { government. }\end{array}$ & $\begin{array}{l}\text { Many similar } \\
\text { Gresik }\end{array}$ \\
\hline
\end{tabular}

Furthermore, from the results of the questionnaire above, a weighting and rating assessment will be carried out to obtain a score on each aspect owned by the company using the IFE matrix and the EFE matrix which will then be combined into the IE matrix to get the company's position in what cell division. 
UMGCINMATIC : $1^{\text {st }}$ Rethinking Education during Covid-19 Era: Challange and Innovation Volume 1 No 2

Table 3. IFE . Matrix

\begin{tabular}{|c|c|c|c|c|c|}
\hline \multirow{2}{*}{ No } & \multirow{2}{*}{ Statement } & \multicolumn{4}{|c|}{ Mark } \\
\hline & & Amount & Weight & Rating & Weight $x$ Rating \\
\hline \multicolumn{6}{|c|}{ Internal Strength Factor (strength) } \\
\hline 1 & Affordable product prices & 13 & 0.09 & 2.6 & 0.234 \\
\hline 2 & Good product taste & 17 & 0.13 & 3.4 & 0.442 \\
\hline 3 & Various products & 13 & 0.1 & 2.6 & 0.260 \\
\hline 4 & Good Free Wifi service & 18 & 0.13 & 3.6 & 0.468 \\
\hline 5 & Strategic location & 19 & 0.14 & 3.8 & 0.532 \\
\hline \multicolumn{6}{|c|}{ Internal Weakness Factors (Weaknesses) } \\
\hline 1 & Insufficient parking space & 17 & 0.13 & 3.4 & 0.442 \\
\hline 2 & Promotion is not maximized & 13 & 0.09 & 2.6 & 0.234 \\
\hline 3 & $\begin{array}{l}\text { Employees are not disciplined in implementing } \\
\text { health protocols }\end{array}$ & 8 & 0.06 & 1.6 & 0.096 \\
\hline 4 & $\begin{array}{c}\text { Health facilities (Handsanitizer) in a sufficient } \\
\text { location }\end{array}$ & 12 & 0.09 & 2.4 & 0.216 \\
\hline \multirow[t]{2}{*}{5} & Poor room conditions & 6 & 0.04 & 1.2 & 0.048 \\
\hline & Amount & & 1 & & 2,972 \\
\hline
\end{tabular}

The IFE matrix in this study was made based on an internal strategic analysis related to the strengths and weaknesses that were considered important which were then given a weight and rating to produce a weighted value. IFE matrix can be seen in table 4.3. Based on the table, it can be seen that the factors that become the company's strengths are: Affordable product prices, good product taste, varied products, good Free Wifi service, and strategic location. The factors that become the company's main weakness are inadequate parking spaces, this is indicated by the weight value $(0.130)$. While promotions are not maximized and health facilities are lacking (providing hand sanitizer) at every table (0.09), from the results of the questionnaire, this is indeed in accordance with the condition of the Kimochi Eatery Restaurant.

Table 4. EFE Matrix

\begin{tabular}{|c|c|c|c|c|c|}
\hline \multirow{2}{*}{ No } & \multirow{2}{*}{ Statement } & \multicolumn{4}{|c|}{ Mark } \\
\hline & & Amount & Weight & Rating & Weight $x$ Rating \\
\hline \multicolumn{6}{|c|}{ External Factors Opportunities (Opportunities) } \\
\hline 1 & Easier access & 12 & 0.11 & 2.4 & 0.264 \\
\hline 2 & The development of technological progress & 17 & 0.15 & 3.4 & 0.510 \\
\hline 3 & Do a lot of orders from customers & 18 & 0.16 & 3.6 & 0.576 \\
\hline 4 & $\begin{array}{l}\text { The existence of the implementation of the New Normal } \\
\text { by the district government. Gresik }\end{array}$ & 19 & 0.17 & 3.8 & 0.646 \\
\hline \multicolumn{6}{|c|}{ External Threats (Threats) } \\
\hline 1 & There are superior competitors & 10 & 0.09 & 2 & 0.18 \\
\hline 2 & $\begin{array}{l}\text { Environmental conditions often flood during the rainy } \\
\text { season }\end{array}$ & 5 & 0.05 & 1 & 0.05 \\
\hline 3 & The emergence of new competitors & 13 & 0.12 & 2.6 & 0.312 \\
\hline
\end{tabular}




\begin{tabular}{|c|c|c|c|c|c|}
4 & Many similar counterfeit products & 16 & 0.14 & 3.2 & 0.448 \\
\hline & Amount & 44 & 1 & & 2,986 \\
\hline
\end{tabular}

\section{Internal External Matrix Design (IE Matrix)}

Based on the IFE matrix which shows that the company is in a moderate position, which is indicated by a score of $(2,972)$ while the EFE matrix produces a score of $(2,986)$, which means the company has moderate external factors. If each of these values is mapped in the IE matrix, then the company's current position is in cell V. In this cell, companies in cell $\mathrm{V}$ are holding and maintaining strategies. Market penetration and product development are the two most common strategies for these types of divisions.

Table 5. SWOT Matrix

\begin{tabular}{|c|c|c|}
\hline Internal factors & $\begin{array}{ll}\text { Strength }(\mathrm{S}) \\
\text { - } & \text { Affordable product prices } \\
\text { - } & \text { Good product taste } \\
\text { - } & \text { Various products } \\
\text { - } & \text { Good Free Wifi service } \\
\text { - } & \text { Strategic location }\end{array}$ & $\begin{array}{l}\text { Weaknesses (W) } \\
\text { - Insufficient parking space } \\
\text { - Promotion is not maximized } \\
\text { - Employees are not disciplined in } \\
\text { implementing health protocols } \\
\text { - Health facilities (Handsanitizer) in a } \\
\text { - } \text { sufficient location } \\
\text { Poor room conditions }\end{array}$ \\
\hline External Factors & & \\
\hline $\begin{array}{l}\text { Opportunities (O) } \\
\text { - Easier access } \\
\text { - The development of } \\
\text { technological progress } \\
\text { - Do a lot of orders from } \\
\text { customers } \\
\text { - The existence of the } \\
\text { implementation of the New } \\
\text { Normal by the district } \\
\text { government. Gresik }\end{array}$ & $\begin{array}{l}\text { SO Strategy } \\
\text { - Kimochi Eatery retains the taste of } \\
\text { the previous recipe } \\
\text { Maintaining fresh food products } \\
\text { from quality ingredients } \\
\text { - Improving the ability and quality of } \\
\text { human resources by conducting } \\
\text { marketing training or increasing } \\
\text { promotions }\end{array}$ & 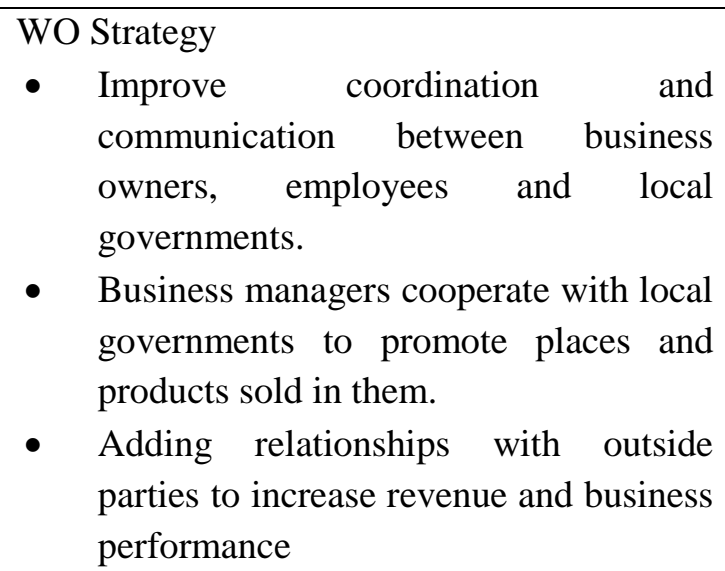 \\
\hline $\begin{array}{l}\text { Threats }(\mathrm{T}) \\
\text { - } \quad \text { There are superior competitors }\end{array}$ & ST strategy & WT Strategy \\
\hline
\end{tabular}




\begin{tabular}{|l|l|l|l|}
\hline $\begin{array}{l}\text { Environmental conditions often } \\
\text { flood during the rainy season } \\
\text { The emergence of new } \\
\text { competitors } \\
\text { Many similar counterfeit } \\
\text { products }\end{array}$ & $\begin{array}{l}\text { Kimochi Eatery restaurant } \\
\text { maintains the quality of business } \\
\text { quality, both product and service } \\
\text { quality } \\
\text { Setting a pricing strategy (price is } \\
\text { able to compete with other similar } \\
\text { businesses) }\end{array}$ & $\begin{array}{l}\text { Improve business management in a better } \\
\text { direction. } \\
\text { Paying attention to the quality of service } \\
\text { quality to consumers } \\
\text { Improve existing facilities and } \\
\text { infrastructure such as stock hand sanitizers } \\
\text { and provide insulation at each table } \\
\text { Utilize online media such as Instagram or } \\
\text { local TV as promotional media. }\end{array}$ \\
\hline
\end{tabular}

\section{IFE Matrix Analysis}

The IFE matrix shows that the main strength of the Kimochi Eatery Restaurant is that it has a strategic location with the highest score of 0.532. By having a strategic location, which is located on the main road of the GKB housing, it will make it easier for consumers to find the location of the Kimochi Eatery Restaurant. Meanwhile, the main weakness faced by Kimochi Eatery Restaurant is that it is shown with the smallest score. The factor that became the main weakness for Kimochi Eatery Restaurant was the poor condition of the room as indicated by a score of 0.048 .

\section{EFE Matrix Analysis}

The main opportunity for companies based on the EFE matrix above is the implementation of the New Normal by the district government. Gresik which is indicated by a score of 0.646 . This external strategy factor is very important because with the implementation of the New Normal policy, customers can come to eat at the place even though they have to maintain health protocols. While the main threats faced by the company are shown in the EFE matrix with the smallest score from the threat factor, namely the conditions around the environment that often flood when the rainy season occurs, which is indicated by a score of 0.05 .

\section{IE Matrix Analysis}

Based on the IFE matrix which shows that the company is in an average position with a score of 2,972, while the EFE matrix produces a score of 2,986 which means that the company has external factors also in the average position. If each of these values is mapped in the IE matrix, then the company's current position is in cell division $\mathrm{V}$. In this cell the company is in an average internal condition with a moderate response to external factors it faces. The right strategy for companies that are in cell $\mathrm{V}$ is a hold and maintain strategy. Market penetration strategy and product development strategy are the two most used strategies for this cell.

\section{SWOT Matrix Analysis}

Based on the SWOT matrix, four main strategies can be drawn up, namely SO strategy, WO strategy, ST strategy and WT strategy. Where each of these strategies has its own characteristics and should be implemented in the next strategy implementation jointly and mutually support each other.

\section{CONCLUSION}

Based on the IFE matrix which shows that the company is in the average position indicated by a score of 2,972. While the EFE matrix produces a score of 2,986 which means the company has external factors also in the average position. If each of these values is placed in the IE matrix, the company's current position is obtained, namely in cell $\mathrm{V}$. In this cell the company is in an average internal condition and the 
response to external factors it faces is classified as moderate. The right strategy for companies in cell $\mathrm{V}$ is a hold and maintain strategy.

\section{REFERENCES}

Kotler, P., Armstrong, G. (2008). Principles Translation marketing. Edition 12, Volume 1. Jakarta: Erlangga.

Rangkuti, F. (2009). SWOT Analysis of Surgical Techniques Business Case. Jakarta: PT. Main Library Gramedia.

Rangkuti, F. (2015). SWOT Analysis of Dissecting Business Case Techniques. Jakarta: PT. Main Library Gramedia.

Siregar, N. (2016). SWOT Analysis as a Basis in Determining Marketing Strategy at PT.Harmony Toba Jaya Medan Company. Journal of Business and Management Concepts, pp. 34-46. Medan: University of Medan Area. Internet.http://ojs.uma.ac.id/index.php/bisman/article/view/236. Access date: 20 May 2021

Secretariat of the Cabinet of the Republic of Indonesia. (2020). President Decides Large-Scale Social Restrictions Option to Overcome the Impact of Covid-19 Internet.https://setkab.go.id/ppresidecukan-social-berskala-large-opsi-atasi-impak-covid-19/. Date accessed 16 June 2021 